\title{
ОБСЕ в Центральной Азии: обсуждение деятельности, связанной с полицейскими функциями
}

\author{
Корнелиус Фризендор $\phi^{*}$
}

\section{Аннотацчия}

Настоящая статья призывает к обсуждению результатов деятельности ОБСЕ, связанной с полицейскими функциями, в Центральной Азии. Опираясь на типологию международного содействия полицейской деятельности, в ней поставлены три вопроса, которые заслуживают более пристального внимания государств-участников и гражданского общества: Может ли ОБСЕ укрепить демократические основы полицейской деятельности в Центральной Азии? В какой степени ОБСЕ может способствовать улучшению гуманитарной безопасности? С какими ограничениями и рисками связана деятельность по поддержке правоохранительных органов? Предварительные данные свидетельствуют о том, что ОБСЕ сталкивается со значительными трудностями при претворении в жизнь своей приверженности демократическим основам полицейской деятельности в Центральной Азии, в основном из-за сопротивления властей центральноазиатских государств. Однако существуют и другие важные факторы, препятствующие стратегическому планированию такой деятельности, включая поддержку правоохранительных органов со стороны других международных акторов, а также институциональные особенности ОБСЕ, в частности, короткие бюджетные циклы. В настоящей статье рассматривается, как государства-участники, заинтересованные в деятельности ОБСЕ по оказанию содействия укреплению демократических основ полицейской деятельности, могут использовать существующие возможности для преодоления существующих ограничений и уменьшения рисков.

\section{Ключевые слова}

ОБСЕ, Центральная Азия, деятельность, связанная с полицейскими функциями, демократическое управление, права человека

Для цитирования этой публикации: Фризендорф К. ОБСЕ в Центральной Азии: Обсуждение деятельности, связанной с полицейскими функциями // ОБСЕ Insights 1. - Баден-Баден: Номос, 2021. URL: https://doi.org/10.5771/9783748921264-01

* Корнелиус Фризендорф, доктор наук, Центр исследований ОБСЕ (CORE) Института исследований проблем мира и политики безопасности при Университете Гамбурга (IFSH), Германия, Friesendorf@ifsh.de 


\section{Введение ${ }^{1}$}

ОБСЕ привержена демократическим основам полицейской деятельности и уже два десятилетия занимается вопросами, связанными с полицейскими функциями. Работа полиции в условиях демократии требует подотчетности и надзора: полиция должна быть подотчетна закону, но не правительству, а независимые органы, такие как парламент и средства массовой информации, должны иметь возможность внимательно следить за ее деятельностью. Демократический подход к полицейской деятельности также требует, чтобы полиция защищала права человека и реагировала на то, что беспокоит население 2 .

Однако на практике ОБСЕ становится все труднее укреплять подотчетность полиции. Незадолго до ухода с поста генерального секретаря ОБСЕ в июле 2020 года Томас Гремингер заявил, что он «обеспокоен ограничением прав человека и инициатив по привлечению полиции к ответственности» ${ }^{3}$. В Центральной Азии ОБСЕ столкнулась с одними из самых серьезных из стоящих перед ней проблем: правительства стран региона обращаются за содействием деятельности их правоохранительных структур и приветствуют инициативы, направленные на повышение ориентированности полиции на оказание услуг, но не очень-то стремятся к закреплению демократических основ полицейской деятельности.

Настоящая статья призывает к обсуждению вопроса о содействии, которое ОБСЕ оказывает полиции центральноазиатских государств. В первом разделе представлен обзор деятельности ОБСЕ, связанной с полицейскими функциями. Во втором рассмотрены практика работы и структуры полиции в Центральной Азии. На этой основе ставятся следующие вопросы:

- Может ли ОБСЕ содействовать утверждению демократических основ полицейской деятельности в Центральной Азии?

- Может ли ОБСЕ оказать государствам содействие в выполнении ими их обязательств в области человеческого измерения?

- В чем заключаются ограничения и риски, связанные с деятельностью по оказанию содействия правоохранительным органам?

Проведенный анализ выявил многочисленные препятствия на пути утверждения демократических основ полицейской деятельности, управления и реформирования сектора безопасности в целом. Важнее всего то, что персонализация власти в Центральной Азии противоречит либеральным демократическим нормам. К числу других препятствий относятся российская оппозиция демократизации, китайские и западные программы «обучения и оснащения», а также скудные ресурсы ОБСЕ и короткие циклы планирования. Эти факторы ограничивают возможности ОБСЕ по реализации ее комплексной повестки дня в области безопасности и делают иностранную поддержку правоохранительной деятельности рискованной для местного населения. 
В заключительном разделе содержатся соображения о том, какие возможности «либеральные» государства-участники могли бы использовать для преодоления существующих ограничений и уменьшения рисков, с которыми приходится считаться при осуществлении в Центральной Азии деятельности, связанной с полицейскими функциями. Эти государства должны стимулировать обсуждение вопросов полицейской деятельности, активно поддерживать демократические основы полицейской деятельности и гражданское общество, а также институты, структуры и присутствия ОБСЕ на местах, ограничивая при этом участие ОБСЕ в собственно правоохранительной деятельности. Более того, ОБСЕ следует более строго оценивать свою деятельность.

\section{ОБСЕ и международное содействие полицейской деятельности}

ОБСЕ - пионер демократической полицейской деятельности. Ее «Руководство по демократическим основам полицейской деятельности» 2008 года стало справочным документом для программ реформирования полиции во всем мире ${ }^{4}$. Многие другие документы также отражают приверженность ОБСЕ данной задаче 5 . В принятом в 2012 г. ключевом решении организации говорится, что деятельность, связанная с полицейскими функциями, должна руководствоваться «нормами, принципами и стандартами, определенными в документах Организации Объединенных Наций и ОБСЕ, таких, как Устав Организации Объединенных Наций, соответствующие конвенции ООН о деятельности, связанной с полицейскими функциями, хельсинкский Заключительный акт, Копенгагенский документ и различные решения ОБСЕ о деятельности, связанной с полицейскими функциями. В этих документах подчеркивается, в частности, значение верховенства права, уважения прав человека и основных свобод, включая гендерные вопросы и вопросы, касающиеся меньшинств; партнерства полиции и населения; эффективных и подотчетных систем уголовного правосудия» ${ }^{6}$.

Полицейская деятельность в первую очередь связана с первым (военно-политическим) измерением ОБСЕ. Однако она также имеет отношение ко второму (например, усилия по борьбе с коррупцией) и третьему (полицейская деятельность, основанная на соблюдении прав человека) измерению. В то время как Постоянный совет представляет собой основной директивный орган, непосредственная деятельность осуществляется исполнительными структурами ОБСЕ: тематическими подразделениями секретариата, в частности, отделом по стратегическим вопросам полицейской деятельности и отделом безопасности границ и пограничного режима, полевыми присутствиями, а также институтами ОБСЕ. Что касается последних, то Бюро по демократическим институтам и правам человека (БДИПЧ) содействует осуществлению полицейской деятельности в соответствии со стандартами в области прав человека, в то время как Верховный комиссар по делам национальных меньшинств 
(ВКНМ) содействует работе многонациональной полиции, а представитель ОБСЕ по вопросам свободы средств массовой информации - свободному освещению вопросов безопасности.

Первая волна деятельности ОБСЕ, связанной с полицейскими функциями, была сосредоточена на Балканах. Там с начала 2000-х годов ОБСЕ внесла значительный вклад в демократизацию полиции, пользуясь такими факторами как широкие мандаты, стремление государств-участников вступить в ЕС и их благожелательное отношение к продвижению демократии ${ }^{7}$. В других регионах ОБСЕ условия были не столь благоприятны.

\section{Виды международного содействия полицейской деятельности}

ОБСЕ подразделяет свою деятельность, связанную с полицейскими функциями, на два основных направления: «общие вопросы развития и реформирования полиции» и «угрозы, создаваемые преступной деятельностью» ${ }^{8}$. Но эти понятия не позволяют провести различие между разными целями оказания содействия полицейской деятельности. В настоящей статье предлагается альтернативная типология, в соответствии с которой можно провести различие между деятельностью, направленной на:

- утверждение демократических основ полицейской деятельности (вид 1);

- улучшение защиты прав человека со стороны полиции (вид 2);

- совершенствование правоприменительной деятельности (вид 3).

Эти виды деятельности отличаются друг от друга с точки зрения их вклада в надзор за деятельностью полиции со стороны независимых институтов, таких как парламент и гражданское общество, что важно, так как внутренний надзор, осуществляемый начальниками полиции и исполнительной властью, зачастую недостаточен для решения проблемы неправомерных действий сотрудников полиции. На укрепление независимого надзора направлен первый вид деятельности, во втором виде деятельности решение этой задачи занимает менее заметное место, а третий вид деятельности вряд играет в ее решении какую-то роль.

Международные акторы могут содействовать утверждению демократических основ полицейской деятельности, поддерживая изменения в правовых основах полицейской деятельности, например, оказывая национальным законодателям содействие в подготовке законопроектов, наделяющих парламент более широкими полномочиями. Международные акторы могут преследовать менее амбициозные цели, к примеру, обучая парламентариев тому, как они могут использовать свои депутатские полномочия или сосредоточить внимание на гражданском обществе, например, обучая журналистов. Внешнее содействие реформам может также предусматривать создание площадок, на которых представители государства и гражданского общества могли бы обсуждать вопросы реформирования полицейской деятельности. 
Международные акторы могут улучшить защзиту безопасности человека со стороны полиции, содействуя сокращению масштабов насилия и коррупции в полиции и повышая тем самым уровень защиты от полиции, например, путем проведения учебных мероприятий, направленных на борьбу с пытками. Такая деятельность также предполагала бы усиление защиты со стороны полиции, в частности, совершенствование мер реагирования полиции на такие проблемы, как насилие в семье или торговля людьми. Деятельность второго вида предполагает прагматическое сотрудничество с полицией и поддержку взаимодействия между полицией и населением, в частности, в рамках концепции полицейской деятельности в общинах. Хотя работа с общинной полицией может предполагать надзор - например, наблюдение за тем, как полиция рассматривает жалобы населения, - он играет меньшую роль, чем в первом виде деятельности.

Международные субъекты могут содействовать совериенствованию правоприменительной деятельности посредством подготовки кадров и оказания материального содействия, направленного на укрепление технической оснащенности государственных структур в таких областях, как уголовное расследование или пограничный контроль. Утверждение демократических основ полицейской деятельности не занимает видного места в третьем виде деятельности, которая также, как правило, связана с международным взаимодействием полицейских структур, а не с взаимодействием государства и общества. Но общество может извлечь выгоду из того, что укрепление государства приводит к более эффективной защите от преступной деятельности и насилия.

У всех трех видов международного содействия есть и свои достоинства, и ограничения. Они также связаны с рядом и рисков. Плюсы и минусы конкретных подходов в значительной степени зависят от местного контекста, в котором они применяются. Особые проблемы в этом отношении возникают в Центральной Азии.

\section{Полицейская деятельность в Центральной Азии}

Демократические основы полицейской деятельности сами по себе являются предметом разногласий, поскольку такие основополагающие принципы, как подотчетность, нуждаются в интерпретации и по-разному применяются на практике даже в либеральных демократиях. Более того, неправомерные действия полиции - проблема во всем регионе ОБСЕ (как показали, например, акции протеста Black Lives Matter летом 2020 года). Тем не менее демократический подход к полицейской деятельности более вероятен в более демократических государствах.

Государства Центральной Азии в индексах прав человека и демократии занимают низкие позиции. «Фридом хаус», измеряя «глобальные показатели свободы» с точки зрения политических прав и гражданских свобод, относит Туркменистан, Таджикистан и Узбекистан к «несвободным» государствам, фактически относя их к 
числу наименее свободных государств мира. Казахстан также считается «несвободным», а Кыргызстан - «частично свободным» государством 9 . Независимо от спорных методологических проблем и нормативных предположений, лежащих в основе таких рейтингов, они помогают понять недемократическую сущность полицейской деятельности в Центральной Азии, что было широко задокументировано международными, неправительственными организациями и СМИ ${ }^{10}$.

Неправомерные действия полиции имеют различные причины, в том числе институциональные стимулы, определяющие поведение сотрудников полиции. Сохраняются некоторые практики, унаследованные с советских времен, такие как давление на полицию с требованием соблюдения нереалистичных квот на раскрытие преступлений, ведущим к применению к подозреваемым насилия с целью принудить их дать признательные показания и таким образом выполнить соответствующие показатели. Низкая заработная плата, нехватка оборудования и недоброжелательное отношение к семьям рядового состава полиции также стимулируют неправомерное поведение сотрудников полиции ${ }^{11}$. Определенную роль играет и политическое давление: власти используют полицию как инструмент для борьбы с политической оппозицией. Там, где политические лидеры предоставляют полиции определенную свободу действий для извлечения незаконной ренты в обмен на политическую лояльность, возникают коррупционные пирамиды, заставляющие рядовых сотрудников полиции делиться этой рентой с начальством.

Проблему представляет также дублирование полномочий силовых структур, о чем свидетельствует увеличение числа специальных подразделений. В Кыргызстане специальные подразделения имеются в министерстве внутренних дел, а также в службе безопасности, национальной гвардии и пограничной службе 12 . В Узбекистане национальная гвардия выполняет функции и поддержания общественного порядка, и борьбы с терроризмом. ${ }^{13}$

В этой системе внешний надзор за полицией слаб. Даже если формальные структуры существуют, их практическая роль часто сводится на нет неформальными нормами, предоставляющими привилегии президентским администрациям, советам национальной безопасности и правоохранительным органам. В результате в последние годы центральноазиатские парламентарии не были склонны бросать вызов исполнительной власти. В Кыргызстане надзор со стороны Жогорку Кенеша (парламента) был «несистемным, неполным и непоследовательным, в то время как парламентский надзор за органами безопасности и правоохранительными органами был еще более ограничен и эпизодичен» ${ }^{14}$. Депутаты сосредоточили свое внимание на неправомерных действиях полиции в нижнем звене, а не на систематическом улучшении ее работы, например, путем усиления надзора за исполнением принятых законодательных актов ${ }^{15}$. Сообщалось, что парламент Узбекистана не обращался в полицию с системными запросами с требованием предоставить документы не в последнюю очередь из-за отсутствия в нем оппозиционных партий, а правозащитники сталкивались с трудностями при взаимодействии с депутатами ${ }^{16}$. Таджикский пар- 
ламент во многом просто штамповал решения, принятые исполнительной властью, а члены парламента не проявляли особого желания обсуждать случаи насилия со стороны полиции, возможно, потому, что многие из них тоже были связаны с силами безопасности ${ }^{17}$.

Надзор со стороны институтов омбудсменов также ограничен. Офис омбудсмена Кыргызстана обладал значительными полномочиями и ресурсами и расследовал большое количество жалоб. Но были сомнения в независимости омбудсмена, не в последнюю очередь из-за его прежней карьеры в спецслужбах, и наблюдатели утверждали, что парламент часто игнорирует его рекомендации ${ }^{18}$. Кроме того, по словам критиков, узбекские и таджикские омбудсмены не проводили должных расследований по жалобам на действия властей, а в Таджикистане вообще отрицали нарушения прав человека ${ }^{19}$.

Эти условия создают не только возможности, но и ограничения и риски для деятельности ОБСЕ, связанной с полицейскими функциями. В следующих разделах изложены три вопроса, требующие обсуждения.

\section{Может ли ОБСЕ содействовать утверждению демократических основ полицейской деятельности в Центральной Азии?}

Поддержка демократических основ полицейской деятельности предполагает изменение характера взаимодействия институтов государства друг с другом и с обществом. Это - наиболее амбициозный вид деятельности, связанной с полицейскими функциями. В силу своей амбициозности она может оказаться слишком сложной задачей для ОБСЕ в Центральной Азии. Фактически существует мало свидетельств систематической поддержки ОБСЕ демократических основ полицейской деятельности в Центральной Азии.

В 2016 г. правительство Кыргызстана прекратило реализацию Инициативы ОБСЕ по обеспечению безопасности на уровне сообществ. Эта инициатива с участием международных полицейских советников была направлена на укрепление доверия между полицией и населением, а также между этническими киргизами и узбекскими общинами на юге страны после вспышки межэтнического насилия в 2010 году. На начальном этапе эта инициатива также оказывала крайне важную поддержку реформе полиции, содействуя проведению дискуссий между властями и экспертами по реформированию полиции из гражданского общества ${ }^{20}$.

Последующие мероприятия были менее амбициозными. Программный офис в Бишкеке продолжал оказывать содействие в проведении обсуждений в общественных советах, но это привело к тому, что требования к МВД оказались довольно умеренными. Показательно, что основным партнером Программного офиса по обсуждению вопросов надзора было именно это министерство, причем офис заявил, что он «поддерживает МВД в продвижении парламентского и общественного надзора» 
за реформой правоохранительных органов ${ }^{21}$. Офис также обсуждал вопросы управления сектором безопасности и его реформирования с академиями государственного управления центральноазиатских государств. Но некоторые киргизские эксперты в области охраны правопорядка считают, что ОБСЕ слишком близка к правительству, недостаточно взаимодействует с критикующими правительство группами и что реформа правоохранительных органов носит поверхностный характер 22 .

В Узбекистане президент Шавкат Мирзиёев стремился повысить роль парламента, в частности, в том, что касается бюджетного надзора ${ }^{23}$. Это расширило возможности для деятельности БДИПЧ и Координатора проектов ОБСЕ в Узбекистане, который помимо прочих инициатив выступил соорганизатором в Узбекистане конференции на тему «Демократизация законодательства и правоприменительной практики» ${ }^{24}$. Однако просьбы об оказании полиции технического содействия, обращенные как к ОБСЕ, так и к другим международным организациям, перевешивали просьбы об оказании содействия по вопросам надзора 25 .

\section{Понимание ограниченности возможностей ОБСЕ}

Способность ОБСЕ поддерживать демократическую полицейскую деятельность определяется преференциями правительств государств-участников ОБСЕ. Несмотря на то, что ОБСЕ представляет собой нечто большее, чем межправительственный форум или инструмент государств, это - организация, основанная на консенсусе, а утверждение демократических основ полицейской деятельности, как правило, не отвечает интересам властей стран Центральной Азии.

Сопротивление демократическому управлению полицией связано с внутренней политической логикой. Генри Хейл раскрывает доминирующую роль в постсоветских режимах «политики патронажа», основанной на системе личных связей, в центре которой, как правило, находятся президенты, обладающие в силу сложившегося понимания правом «казнить и миловать» ${ }^{26}$. Члены доминирующих групп занимают официальные посты, но существующая система связей распространяется и на негосударственные секторы, ставя под вопрос разграничение между государством и обществом, на котором основывается концепция демократического управления и реформирования сектора безопасности. Надзор со стороны государственных институтов, таких как парламент, как правило, неэффективен, поскольку элиты не бросают вызов патронам до тех пор, пока считают их сильными. Неформальные нормы, сформировавшиеся на основе личных связей, важнее убеждений и абстрактных принципов. Для основанных на принципах патронажа систем характерны высокий уровень коррупции и низкий - верховенства права. Политические процессы и даже насильственное свержение правительств здесь не следует путать с демократизацией. Напротив, такие процессы означают, что меняющиеся ожидания элиты приводят к власти новые группы, опирающиеся на свои личные связи. По мнению Хейла, 
международным акторам не хватает рычагов воздействия и связей для изменения основанной на принципах патронажа политики на постсоветском пространстве 27.

Для либералов это - пессимистический взгляд на перспективы укрепления демократических основ полицейской деятельности. Западные правительства могут попытаться определить направления деятельности по утверждению демократических основ и выделить на эти цели внебюджетное финансирование, не требующее консенсуса всех государств-участников. Тем не менее им придется столкнуться с серьезными препятствиями. Переход к эффективному контролю над исполнительной властью и ее институтами создаст проблему для доминирующих во власти групп. Более того, внедрение демократических основ полицейской деятельности потребовало бы укрепления официальных, а не неформальных норм, а это в лучшем случае - медленный, постепенный процесс.

Еще в 2005 году в одной из оценок говорилось, что «климат для реформирования сектора безопасности в Центральной Азии неблагоприятен вследствие как глобальной «войны с террором», так и характера преобладающих в регионе политических режимов. Слабые законодательные и судебные органы, выхолощенные СМИ и низкий уровень активности гражданского общества лишь усилили консервативность центральноазиатских режимов» ${ }^{28}$. Пятнадцать лет спустя риторических заявлений о приверженности реформам стало еще больше. Тем не менее в управлении полицией не удалось добиться больших успехов, что подтверждает справедливость вывода о жизнестойкости системы, основанной на патронаже.

\section{Контроль за деятельностью ОБСЕ}

У центральноазиатских государств есть различные способы предотвращения деятельности ОБСЕ, в которой они не заинтересованы. Прежде всего, они как члены организации с равными правами не только принимают у себя полевые присутствия, но и принимают решения о них и контролируют формулировки их мандатов.

Мандаты становятся все более ограниченными, что проявляется в изменениях и модификациях, которые приводят в том числе к изменению названий: Центр ОБСЕ в Астане в 2015 году стал офисом программ в Астане. В 2006 году Центр ОБСЕ в Узбекистане был преобразован в бюро координатора проектов ОБСЕ. Центр ОБСЕ в Бишкеке в 2016 году был преобразован в программный офис ОБСЕ, а офис в Оше был закрыт. В 2017 году бюро ОБСЕ в Душанбе было заменено программным офисом. В Туркменистане все еще действует Центр ОБСЕ в Ашгабате, но его полномочия ограничены.

В Центральной Азии власти контролируют не только принятие политических решений, но и их реализацию. Они требуют согласовывать с ними осуществляемую деятельность, часто вплоть до уровня конкретных проектов. Они делают интерпретирующие заявления, которые вынуждают исполнительные структуры ОБСЕ осу- 
ществлять только такую деятельность, которая непосредственно предусмотрена в мандатах, что значительно ограничивает автономию исполнителей. С интерпретирующими заявлениями выступает и Россия ${ }^{29}$.

Косвенно на деятельности сказываются и предпочтения властей: исполнительные структуры ОБСЕ не хотят рисковать. Международные сотрудники в штаб-квартире и на местах предвидят, какую деятельность не одобрят власти государств Центральной Азии, и грешат чрезмерной осторожностью. На местный персонал полевых присутствий не распространяются правила, устанавливающие максимальные сроки найма. Однако у него еще больше причин для осторожности, чем у международного персонала. Правовая защита со стороны ОБСЕ, в том числе освобождение от налогов, - постоянный камень преткновения на переговорах по меморандумам о взаимопонимании с принимающими государствами. Слабый правовой статус ОБСЕ затрудняет выполнение организацией ее обязанности проявлять заботу о сотрудниках $^{30}$. У местного персонала также мало шансов продвинуться по служебной лестнице в рамках ОБСЕ (это - «не кадровая организация»). Местные сотрудники следят за вакансиями на рынке труда, в том числе на государственной службе, и это не мотивирует их отстаивать политически рискованные инициативы в области управления.

Еще одно институциональное препятствие на пути достижения долгосрочных целей, таких как повышение эффективности управления, связано с финансированием. Бюджетный цикл ОБСЕ, как правило, составляет один год, и значительная доля средств зависит от финансирования внебюджетных проектов, поступающего в течение года. Это препятствует стратегическому планированию и достижению амбициозных целей, таких как демократическое управление. Опубликованная в 2013 году оценка деятельности ОБСЕ в области управления и реформирования сектора безопасности по-прежнему достаточно точно описывает деятельность ОБСЕ, связанную с полицейскими функциями, в Центральной Азии:

«Проекты зачастую носят разовый характер, основываются на запросах государств-участников и наличии специалистов, которых можно привлечь в короткие сроки; их структура определяется приоритетами отдельных государств, выделяющих внебюджетное финансирование и прикомандированный персонал. В результате проекты зачастую не становятся звеном в “цепочке” мероприятий, преследующих достижение более широкой цели, что значительно снижает эффект от их реализации» ${ }^{31}$.

Разумеется, полевые присутствия можно планировать на несколько лет вперед. Однако неопределенность в отношении продления мандата, риск того, что принимающие государства больше не дадут согласие на реализацию даже тех программ, которые были включены в меморандумы о взаимопонимании, и возможный дефицит финансирования создают неопределенность. Поэтому с бюрократической точки зрения планирование деятельности возможно только на краткосрочную перспективу. 
Если у исполнительных структур ОБСЕ мало возможностей для маневра в продвижении демократических основ полицейской деятельности в Центральной Азии, то как насчет усилий по улучшению обеспечения гуманитарной безопасности со стороны полиции?

\section{Может ли ОБСЕ содействовать обеспечению гуманитарной безопасности в Центральной Азии?}

Гуманитарная безопасность - свобода людей от страха и нужды - относится в первую очередь к человеческому измерению ОБСЕ. Деятельность второго вида, направленная на борьбу с торговлей людьми, гендерным насилием и реформирование пенитенциарной системы, в меньшей мере, чем демократическое управление, затрагивает ключевые вопросы государственности. По этой причине авторитарные государства, видящие в ней возможность повысить свою легитимность, относятся к ней терпимо или даже стремятся к сотрудничеству. Более того, эту деятельность можно гибко адаптировать к местным условиям, что согласуется с общим настроем против тиражирования типовых решений - подхода, свойственного специалистам, занимающимся поросами управления и реформирования сектора безопасности. Деятельность второго вида, к примеру, такая как оказание содействия в формировании общинной полиции, как правило, носит инклюзивный характер и тем самым вписывается в историческую объединительную традицию ОБСЕ, предлагающей придерживающимся разных позиций государствам или общественным группам площадки для поиска компромиссных решений.

По этим причинам в последние годы мероприятия второго вида составили значительную часть деятельности ОБСЕ, связанной с полицейскими функциями, в Центральной Азии, и были тщательно адаптированы к повестке дня соответствующих правительств. Они включали в себя проведение конференций, семинаров и круглых столов, а также учебных мероприятий; подготовку справочников; проведение кампаний по повышению осведомленности и организацию ознакомительных поездок для должностных лиц центральноазиатских стран ${ }^{32}$.

После прекращения властями Кыргызстана реализации Инициативы ОБСЕ по обеспечению безопасности на уровне сообществ ОБСЕ продолжала оказывать поддержку общинной полиции, финансируя полицейские автобусы (передвижные полицейские приемные), которые способствуют взаимодействию полиции и населения в отдаленных районах, а также продолжая поддерживать местные общественные советы, участвующие в управлении этой программой. Программный офис в Бишкеке также содействовал повышению безопасности дорожного движения, организовал переподготовку кадров для обучения применению новых законов об уголовном правосудии, содействовал предотвращению пыток, защите прав жертв торговли людьми, а также внедрению кодекса поведения для полиции. 
В Узбекистане ОБСЕ поддерживает в последние годы усилия президента по повышению качества государственных услуг и борьбе с вопиющими нарушениями прав человека. В результате предупреждение пыток стало важной частью повестки дня бюро Координатора проектов в Узбекистане и других исполнительных структур ОБСЕ ${ }^{33}$. Другие мероприятия были посвящены проблемам торговли людьми и поддержке усилий властей по созданию в правоохранительных органах структур по связи с общественностью и по борьбе с насильственным экстремизмом и радикализацией, ведущими к терроризму.

Даже в Таджикистане ОБСЕ сохранила в повестке дня вопросы гуманитарной безопасности, организовав мероприятия, сосредоточенные на таких проблемах, как гендерное насилие, предупреждение пыток и ювенальная юстиция. Она содействовала работе полиции на уровне общин путем финансирования и оснащения типовых полицейских участков, обучения сотрудников полиции реагированию на запросы общественности и оказания поддержки общественным советам, объединяющим представителей полиции и общин.

\section{Проблемы в области обеспечения гуманитарной безопасности}

Такие мероприятия оказали реальную помощь многим людям, как, например, в Кыргызстане, где, по данным ОБСЕ, многие обращались к спонсируемым ею мобильным полицейским командам. Однако эмпирические данные и результаты исследований в других областях вызывают вопросы о том, насколько обоснованы предположения, которые, как представляется, лежат в основе этой деятельности ОБСЕ.

Во-первых, поддержка гражданского общества со стороны ОБСЕ предполагает, что организация исходит из того, что гражданское общество может быть наделено правами и возможностями, и что участие гражданского общества изменит поведение полиции. Однако возникают различные вопросы, связанные с поддержкой гражданского общества, включая асимметрию власти. В центральноазиатских общественных советах, служащих площадками для обсуждения реформы полицейской деятельности, как правило, доминируют сотрудники МВД и силовых структур. В одной из оценок ситуации в Таджикистане такие советы были названы «управляемыми государством» ${ }^{34}$. Более того, члены организаций гражданского общества могут не представлять уязвимые группы населения. То, как власть имущие, например, старейшины-мужчины, относятся к домашнему насилию, может не соответствовать либеральным нормам. Термин «гражданское общество» также подразумевает четкое различие между государством и обществом, что игнорируется в системах власти, основанных на патронаже.

Второе предположение, которое, как представляется, лежит в основе деятельности ОБСЕ по укреплению гуманитарной безопасности, - возможность изменения 
поведения полиции путем изменения ее ценностных ориентиров. Действительно, стремление изменить ценностные ориентиры имеет долгую историю в СБСЕОБСЕ ${ }^{35}$. Есть надежда, что взаимодействие с гражданским обществом и международными экспертами, разъясняющими международные нормы и передовой опыт, будет способствовать социализации полиции и приведению ее поведения в соответствие с этими нормами. К сожалению, теория организаций ставит под сомнение перспективу изменения ценностной ориентации полиции посредством разовых мероприятий. Внутренняя культура и порядки в организациях меняются медленно, так как они формируются и воспроизводятся по мере того, как молодые сотрудники полиции приобщаются к ним, а также под влиянием иерархических отношений, обучения и давления со стороны коллег ${ }^{36}$. Более того, нормы поведения в организации формируются под влиянием политики. Коррупция на высоком уровне посылает сигнал о том, что можно мириться с уличной коррупцией. Группы, действующие в рамках системы патронажа, также могут наказывать «агентов перемен», призывающих к глубоким реформам.

Третье предположение, которое также, похоже, лежит в основе деятельности ОБСЕ, заключается в том, что маленькие шаги будут обретать собственную динамику. Реформаторы полицейской деятельности могут надеяться, что пилотные модельные полицейские участки будут развернуты по всей стране. Тем не менее государство может остановить реализацию или выхолостить проекты в области общинной полиции, как это случилось с Инициативой ОБСЕ по обеспечению по безопасности на уровне сообществ в Кыргызстане. Реформа полицейской деятельности может продолжаться более десяти лет, но не привести к утверждению демократических основ этой деятельности, как это продемонстрировал пример Таджикистана. Центральноазиатские государства умеют ускорять или замедлять реформы и контролировать их содержание.

Деятельность второго вида сталкивается с этими ограничениями и связана с риском превратиться в поддержку авторитарной модернизации (то есть усилий нелиберальных государств по повышению своей легитимности без изменения системы правления, основанной на патронаже). Эти ограничения и риски должны быть сопоставлены с улучшениями в области гуманитарной безопасности, а при следующем виде содействия полиции они будут еще выше.

\section{Ограничения и риски деятельности по оказанию содействия правоохранительным органам}

Оказываемая правоохранительным органам помощь может способствовать более эффективному предотвращению и расследованию преступлений полицией. Она может также привести полицейскую практику в соответствие с обязательствами в об- 
ласти прав человека, например, если полиция будет полагаться на судебно-медицинские доказательства, а не на сделанные под давлением признания.

Деятельность третьего вида занимает центральное место в работе ОБСЕ с полицией в Центральной Азии. Ежегодные отчеты генерального секретаря о деятельности, связанной с полицейскими функциями, содержат обширные перечни мероприятий с участием ОБСЕ в таких областях как борьба с организованной преступностью, расследование и анализ уголовных дел, трансграничное сотрудничество по уголовным делам, борьба с финансированием терроризма, вооруженного экстремизма и радикализации, ведущими к терроризму, незаконным оборотом наркотиков и химических прекурсоров, финансовые расследования, борьба с отмыванием денег и конфискацией преступных доходов, борьба с торговлей людьми и с преступлениями, связанными с миграцией, безопасность границ и киберпреступность. ОБСЕ оказывает содействие в основном посредством подготовки кадров и предоставления оборудования. Помимо этого обмену передовым опытом и созданию транснациональных полицейских сообществ служат международные ознакомительные поездки.

Мероприятия третьего вида популярны по нескольким причинам. Прежде всего, власти стран Центральной Азии стремятся получить поддержку для своих правоохранительных органов. Они нередко жалуются на то, что ОБСЕ не предоставляет им достаточно средств ${ }^{37}$. Другой ключевой момент - институциональные движущие силы в рамках ОБСЕ. Исполнители политики ОБСЕ, такие как сотрудники отдела по стратегическим вопросам полицейской деятельности, часто имеют опыт работы в сфере безопасности и поэтому склонны к повышению полицейского потенциала. Поддержка правоохранительных органов позволяет секретариату и полевым присутствиям отчитываться о своей деятельности, обеспечивать финансирование и быстро тратить деньги. Исследователи утверждают, что не столько ОБСЕ социализировала центральноазиатские государства, сколько последние социализировали ОБСЕ как инструмент сохранения статус-кво ${ }^{38}$.

Помимо этого, техническое содействие полиции оказывают и другие международные акторы, что заставляет ОБСЕ делать то же самое, чтобы центральноазиатские государства считали ее важным партнером. Примерами могут служить поддержка Европейским Союзом пограничного контроля, полицейские программы Управления ООН по наркотикам и преступности, а также двусторонняя помощь правоохранительным органам со стороны США. Многие программы экстернализируют западные внутренние проблемы, связанные с незаконным оборотом наркотиков, терроризмом или незаконной миграцией (в частности, с угрозами безопасности, исходящими из Афганистана), что приводит к непреднамеренному эффекту усиления центральноазиатских силовых министерств ${ }^{39}$. Россия также тесно сотрудничает с центральноазиатскими силами безопасности, в то время как Китай все больше экспортирует туда свою собственную полицейскую практику, которая зачастую нарушает демократические основы полицейской деятельности. 


\section{Поддержка правоохранительной деятельности как способ оказания влияния?}

В соответствии со своей всеобъемлющей повесткой дня в области безопасности ОБСЕ регулярно включает в программы технического содействия полицейской деятельности положения о правах человека. В принципе оказание технического содействия полиции дает возможность предусмотреть в этой деятельности решение вопросов прав человека, предусмотрев, например, обсуждение международных обязательств и национальных норм, запрещающих применять пытки к лицам, содержащимся под стражей, подготовку практических рекомендаций, таких как не слишком сильное затягивание наручников. Однако на практике в таких оптимистических оценках воплощения идеи всеобъемлющего подхода к безопасности недооценивается способность центральноазиатских государств к микроуправлению техническим содействием и преувеличивается готовность исполнительных структур ОБСЕ к риску конфронтации с принимающими государствами в случае творческого подхода к осуществлению их мандата.

Утверждается также, что техническое содействие способствует укреплению демократических основ полицейской деятельности. Однако Дэвид Бейли предостерегает международных акторов, что материальную помощь следует предоставлять «только для покрытия расходов на проведение [демократических] реформ, которые хотят осуществить сами местные власти, а не для того, чтобы стимулировать приверженность реформам среди людей, которые в противном случае не желали бы их ${ }^{40}$. Более того, обучение не дает устойчивого эффекта, если приобретенные навыки не применяются на практике. В Центральной Азии внутренние институциональные условия препятствуют применению навыков, полученных в ходе реализации финансируемых за счет иностранных источников учебных программ в области прав человека.

Деятельность третьего виде не только может быть неэффективной с точки зрения утверждения демократических основ полицейской деятельности, но и сопряжена со значительными рисками в условиях авторитаризма. Критики указывают на опасность того, что спонсируемая ОБСЕ помощь правоохранительным органам может непреднамеренно способствовать усилению репрессий ${ }^{41}$. Другие риски менее заметны, в частности, - поддержание легитимности авторитарного правления. Центральноазиатские государства говорят на языке демократической правоохранительной деятельности, что облегчает западным правительствам выделение средств на оказание помощи. Вербальное принятие глобальных концепций, таких как гендерный подход, особенно без четких «дорожных карт» и последующего мониторинга, не ведет к изменению властных отношений. Так, в Вене в начале 2018 года министр внутренних дел Таджикистана «представил приоритетные области, нуждающиеся в дальнейшей поддержке со стороны государств-участников ОБСЕ, особо упомянув такие вопросы как новая полицейская форма, закупка нового оборудования для по- 
лиции и автоматизация всех процессов коммуникации в структурах МВД. В ходе последовавшей за этим дискуссии министр затронул вопросы общинной полиции и гендерного равенства» ${ }^{42}$.

\section{Выводы и рекомендации}

Публичное обсуждение проблем осуществляемой ОБСЕ в Центральной Азии деятельности, связанной с полицейскими функциями, о которых говорится в данной статье, практически не ведется. Несмотря на то, что отчеты ОБСЕ весьма оптимистичны, нет никаких свидетельств того, что организация осмыслила критику прошлых лет, и многие лежащие в основе этой деятельности предположения остаются непроверенными.

Хотя нам не хватает знаний о том, какие формы оказания иностранного технического содействия полиции являются наиболее эффективными, существующая литература позволяет сделать выводы по крайней мере о том, что, похоже, должного эффекта не дает. Государства-участники, заинтересованные в осуществляемой ОБСЕ в Центральной Азии деятельности, связанной с полицейскими функциями, могли бы предпринять следующие шаги:

- Инициировать обсуждение связанной с полищейскими функциями деятельности. Государствам-участникам следует обсудить существующие возможности, ограничения и риски, с которыми сталкивается деятельность ОБСЕ, связанная с полицейскими функциями, в рамках Постоянного совета, Комитета ОБСЕ по вопросам безопасности и Группы друзей управления и реформирования сектора безопасности. Им следует подчеркнуть, что данная деятельность имеет отношение к различным измерениям ОБСЕ и в силу этого обстоятельства неразрывно связана с человеческим измерением. Помимо этого западным государствам следует улучшить работу полиции у себя дома, чтобы создать для других стран примеры для подражания, а также изучить способы, с помощью которых ОБСЕ могла бы оказывать более эффективную поддержку реформированию полицейской деятельности в том числе к западу от Вены.

- Подвергнуть сомнению концеепци и заявления о достигнутых успехах. Вместо содержащихся во многих общедоступных докладах ОБСЕ заявлений, преуменьшающих трудности выполнения принятых в рамках ОБСЕ обязательств и подменяющих концепции демократических основ полицейской деятельности, управления и реформирования сектора безопасности, наращивания потенциала модными словами, государства должны внимательно изучить вопрос о том, соответствует ли риторика ОБСЕ практике. Например, государствам следует подчеркивать, что оказание материальной и экспертной поддержки силам безопасности, не сопровождающееся прогрессом в сфере надзора за их деятельностью, является нару- 
шением всеобъемлющего подхода к безопасности, лежащего в основе деятельности ОБСЕ. С учетом вызовов, порождаемых политикой государств Центральной Азии и сопротивлением России демократизации, государства-участники должны провести более тщательную оценку соответствия риторики ОБСЕ практике ее деятельности (см. ниже).

- Найти сторонников перемен. Международным акторам не хватает в Центральной Азии рычагов влияния и связей, которыми они располагают в других частях мира. Более того, демократическая полицейская деятельность не может осуществляться в изоляции. Она зависит от более широкой стратегии управления и реформирования сектора безопасности и, более того, от демократизации в целом, которая представляет собой долгосрочный процесс даже в отсутствие системы патронажа, характерной для Центральная Азии. Тем не менее ОБСЕ может оказать поддержку национальным сторонникам перемен, в частности, в критические моменты, когда для этого существуют политические условия (как она это сделала в Кыргызстане после революции 2010 года). ОБСЕ должна определить наиболее многообещающих сторонников перемен и признать, что их поддержка - политический, а не технический процесс и как таковая требует компромисса. Группы гражданского общества, разделяющие ценности ОБСЕ, могут не быть влиятельными, в то время как влиятельные группы могут быть частью режима.

- Поддержать гражданское общество. Гражданское общество - важнейший элемент продвижения человеческого измерения, несмотря на проводимую государствами политику его кооптации и маргинализации. Государства-участники должны обеспечить, чтобы полевые присутствия работали в том числе с группами гражданского общества, критически относящимися к властям. В Центральной Азии есть опытные аналитики и сторонники реформы полицейской деятельности, которые могли бы извлечь пользу из систематической поддержки со стороны ОБСЕ, в частности, путем консультирования по таким вопросам, как формирование коалиций, финансовый менеджмент, составление отчетов. К другим направлениям деятельности относятся обучение журналистов подготовке статей о полицейской деятельности, финансовая и политическая поддержка исследований проблем реформирования полиции и надзора за ее деятельностью, а также проблем управления и реформирования сектора безопасности в целом, как, например, это делается в Академии ОБСЕ в Бишкеке. Политическая и финансовая поддержка молодежных и образовательных инициатив в Центральной Азии заслуживает особого рассмотрения в качестве долгосрочной инвестиции в институциональные изменения.

- Поддержсвать исполнительные структуры ОБСЕ. Структурам ОБСЕ, секретариату и полевым присутствиям необходима финансовая поддержка проектов первого и второго вида, в том числе в рамках внебюджетного процесса. Они также нуждаются в политической поддержке, например, в гарантиях того, что со- 
трудники ОБСЕ, включая местный персонал, не будут брошены на произвол судьбы, если они вызовут недовольство принимающих государств, например, работая с настроенными на реформы неправительственными организациями.

- Ограничить поддержку правоохранительных органов со стороны ОБСЕ. Риски, связанные с деятельностью третьего вида, направленной на укрепление правоохранительных органов, могут перевешивать выгоды для населения Центральной Азии. Нельзя считать панацеей увязывание вопросов содействия правоохранительным органам с решением задач по совершенствованию управления, укреплению гуманитарной безопасности, или «включением» прав человека в программы оказания содействия правоохранительным органам. Центральноазиатские государства умеют создавать демократические фасады и микроуправляемые проекты, а принцип консенсуса оставляет мало места для выдвижения условий в стиле ЕС. Сокращение или прекращение политической поддержки и финансирования программ «обучения и оснащения» соответствовало бы принципу «не навреди». Демократические государства также должны переосмыслить помощь, оказываемую правоохранительным органам стран Центральной Азии другими международными организациями и на двусторонней основе, чтобы уменьшить конкурентное давление на ОБСЕ. Можно возразить, что ограничение технического содействия правоохранительным органам лишит западные государства возможности сотрудничать со странами Центральной Азии в борьбе с транснациональными угрозами для безопасности. Но сторонники этой точки зрения недооценивают негативные последствия не основанной на нравственных принципах помощи не только для ситуации в области прав человека на местном уровне, но и для интересов Запада. В конце концов, репрессии создают благодатную почву для преступности и политического насилия.

Главная предпосылка для обсуждения и предложенного выше совершенствования деятельности ОБСЕ, связанной с полицейскими функциями, - ее оценка. Государства-участники должны тщательно анализировать деятельность секретариата и присутствий на местах и лежащую в ее основе логику, а также систематически запрашивать, анализировать и обсуждать оценки службы внутреннего надзора. Самооценки полевых присутствий также заслуживают более тщательного анализа, а внеплановые аудиты могут дополнительно повысить прозрачность этой деятельности. Кроме того, ОБСЕ могла бы извлечь пользу из большего числа внешних независимых оценок и применения инновационных методологий, подобных тем, которые используют этнографы. Подробные описания или опросы о доверии общества к полиции подвергаются критике из-за неизбежных неточностей. Тем не менее, использование таких методов зачастую формирует лучшее понимание проблем, чем бюрократическая «работа для галочки» и внедрение новых моделей в сфере государственного управления. 
Государства-участники должны также обсудить вопрос об обнародовании информации, которая позволила бы вести открытое и квалифицированное обсуждение этих проблем. ОБСЕ выпускает большое количество информации, но общедоступные документы не дают ответы на многие вопросы. Общественность мало знает о теориях перемен и лежащих в их основе предположениях, о том, какие государства выделяют внебюджетное финансирование на те или иные проекты или планы по управлению рисками. Один из способов решения этой проблемы - создание наблюдательных органов для конкретных проектов и программ, которые делились бы с общественностью своими выводами.

Самое главное: оценки должны быть сосредоточены на том, изменила ли деятельность ОБСЕ поведение полиции (результат) и повлияла ли она на преступность и насилие в обществе (воздействие). Это, как известно, трудно оценить в силу таких факторов, как экономические или демографические изменения. Применительно к деятельности ОБСЕ, связанной с полицейскими функциями, трудности усугубляются скудостью надежных данных, предоставляемых властями стран Центральной Азии, и оказанием помощи полиции этих стран другими международными донорами. Влияние «мягкой силы», в частности, распространение норм, в котором ОБСЕ является лидером, также трудно измерить.

Несмотря на то, что оценки деятельности ОБСЕ, связанной с полицейскими функциями, неизбежно останутся неполными, центральное обоснование этой деятельности не должно остаться без тщательного анализа. Существует риск просто предположить, что ОБСЕ не сможет решить сложные проблемы в сложной политической обстановке с небольшим бюджетом, но без ОБСЕ работа полиции в Центральной Азии была бы еще хуже. Хотя это может быть правдой, но непроверенные предположения редко приводят к хорошей политике.

\section{Примечания}

1 Благодарю моих собеседников, поделившихся со мной своими взглядами. За замечания по более раннему варианту статьи благодарю представителей Института исследований проблем мира и политики безопасности (IFSH) и внешних рецензентов, а также Кэролайн Тейлор за ее редакторские предложения.

2 См.: Bayley D. Changing the Guard: Developing Democratic Police Abroad. - Oxford: Oxford University Press, 2006. P. 18-22.

3 Annual Report of the Secretary General on Police-Related Activities 2019. 2020. 2 July. P. 2 // Официальный сайт ОБСЕ. URL: https://www.osce.org/files/f/documents/2/6/456052.pdf

4 Руководство по демократическим основам полицейской деятельности // Официальный сайт ОБСЕ. URL: https://www.osce.org/ru/secretariat/23805.

5 См.: Annual Report of the Secretary General on Police-Related Activities 2018. 2019. 8 August. P. 157-162 // Официальный сайт ОБСЕ. URL: https://www.osce.org/secretariat/427427. 
6 Решение Постоянного совета № 1049: Стратегическая концепция ОБСЕ в отношении деятельности, связанной с полицейскими функциями. PC.DEC/1049, 26 июля 2012. С. 3. // Официальный сайт ОБСЕ. URL: https://www.osce.org/pc/92559.

7 Eckhard S. International Assistance to Police Reform: Managing Peacebuilding. - Basingstoke: Palgrave Macmillan, 2016. Chapter 3.

8 См.: Annual Reports of the Secretary General on Police-Related Activities // Официальный сайт ОБСЕ. URL: https://www.osce.org/spmu/108393.

9 Countries and Territories, Global Freedom Scores. 2020. 5 June // Freedom House. URL: https:// freedomhouse.org/countries/freedom-world/scores?sort=asc\&order=Total $\% 20$ Score $\% 20$ and $\% 20$ Status.

10 См., например: Torture in Central Asia: Time to Break the Vicious Circle. 2019. 26 June. // International Partnership for Human Rights. URL: https://www.iphronline.org/torture-in-central-as ia-time-to-break-the-vicious-circle.html.

11 См. более ранний, но сохраняющий свою актуальность анализ: Central Asia: The Politics of Police Reform. International Crisis Group. Asia Report № 42. 2002. 10 December. URL: https:// d2071 andvip0wj.cloudfront.net/42-central-asia-the-politics-of-police-reform.pdf.

12 Разговор автора с экспертом по безопасности, Бишкек, 7 марта 2019 года.

13 Hashimova U. The National Guard of Uzbekistan: Rising Profile, Lingering Problems // The Diplomat. 2019. 22 February. URL: https://thediplomat.com/2019/02/the-national-guard-of-uzbe kistan-rising-profile-lingering-problems/.

14 Alymbaeva A., Burnashev R., Jasutis G. et al. Parliamentary Oversight of the Security Sector: Case Studies from Central Asia. - Geneva: Geneva Centre for Security Sector Governance (DCAF), 2020. P. 28.

15 Разговор автора с киргизской НПО, Бишкек, 11 марта 2019 года.

16 Разговор автора с членом НПО и правозащитной группой, Ташкент, июнь 2019 года.

17 Alymbaeva A., Burnashev R., Jasutis G. et al. Op cit. P. 47-54.

18 Ibidem. Р. 33; разговор автора с киргизской НПО, Бишкек, март 2019 года.

19 Встречи автора с правозащитниками, Ташкент, июнь 2019 года; общение с таджикским исследователем, 2019 год.

20 См.: Marat E. The Politics of Police Reform: Society against the State in Post-Soviet Countries. - Oxford: Oxford University Press, 2018.

21 Annual Report of the Secretary General on Police-Related Activities 2018. P. 120.

22 Разговоры с представителями НПО, Бишкек, март 2019 года.

23 Разговор с сотрудником посольства родной из стран Запада, Ташкент, июнь 2019 года.

24 Annual Report of the Secretary General on Police-Related Activities 2018. P. 145.

25 Разговоры с представителями ООН, Ташкент, июнь 2019 года.

26 Henry E. Hale, Patronal Politics: Eurasian Regime Dynamics in Comparative Perspective, New York: Cambridge University Press, 2015.

27 Ibidem. P. 442-445.

28 Security System Reform and Governance. DAC Guidelines and Reference Series // Organization for Economic Co-operation and Development (OECD). 2005. 31 May. P. 24. URL: https://www. oecd-ilibrary.org/development/security-system-reform-and-governance_9789264007888-en.

29 Пример такого заявления см.: Решение № 1251 Постоянного совета. Программный офис в Душанбе. PC.DEC/1251, 1 июня 2017 // Официальный сайт ОБCE. URL: https://www.osce.o $\mathrm{rg} / \mathrm{ru} /$ permanent-council/328056.

30 См.: The Legal Framework of the OSCE / M. Steinbrück Platise, C. Moser, A. Peters (eds.). Cambridge: Cambridge University Press, 2019. 
31 The Role of the Organization for Security and Co-operation in Europe (OSCE) in Security Sector Governance and Reform // DCAF. 2013. 20 December. P. 23. URL: https://www.dcaf.ch/site s/default/files/publications/documents/OSCE_SSG_Mapping_Study_Final_Report.pdf.

32 См.: Annual Reports of the Secretary General on Police-Related Activities.

33 О программе ОБСЕ по подготовке должностных лиц Узбекистана по вопросам прав человека при проведении антитеррористических расследований см.: OSCE, Annual Report of the Secretary General on Police-Related Activities 2018. P. 140.

34 Bakhtaliev O. The Evolving Role of Civil Society in Peace and Security in Tajikistan: Challenges and Opportunities. // Saferworld. 2020. 17 March. URL: https://www.saferworld.org.uk/r esources/news-and-analysis/post/861-the-evolving-role-of-civil-society-in-peace-and-security-in -tajikistan-challenges-and-opportunities.

35 Cronin B. Creating Stability in the New Europe: The OSCE High Commissioner on National Minorities and the Socialization of Risky States // Security Studies. Vol. 12. 2002. № 1. P. 132-163.

36 Friesendorf C. How Western Soldiers Fight: Organizational Routines in Multinational Missions. - Cambridge: Cambridge University Press, 2018. Chapter 4.

37 См.: Рухулло С. Программа реформирования полиции: вопросы без ответов // Радио Озоди. 2020. 23 февраля. URL: https://rus.ozodi.org/a/30449643.html.

38 Kluczewska K. Benefactor, Industry or Intruder? Perceptions of International Organizations in Central Asia - The Case of the OSCE in Tajikistan // Central Asian Survey. Vol. 36. 2017. № 3, P. 353-372.

39 De Danieli F. Counter-Narcotics Policies in Tajikistan and Their Impact on State Building // Central Asian Survey. Vol. 30. 2011. № 1. P. 129-145.

40 См.: Bayley D. Op. cit. P. 64.

41 Lewis D. Reassessing the Role of OSCE Police Assistance Programing in Central Asia. Occasional Paper Series No. 4. April 2011. // Open Society Foundations. URL: https://www.opensoci etyfoundations.org/publications/reassessing-role-osce-police-assistance-programing-central-asia. Annual Report of the Secretary General on Police-Related Activities 2018. P. 124. 
